\title{
Escravos sem senhores: escravidão, trabalho e poder no Mundo Romano ${ }^{1}$
}

Norberto Luiz Guarinello

USP

RESUMO

O artigo aborda a escravidão no Império Romano, discutindo as fronteiras entre liberdade e escravidão em seus aspectos públicos e privados. Central para a discussão é a noção de trajetória escrava, que coloca os alforriados numa espécie de limbo social, uma zona de indeterminação que contamina a sociedade escravista romana como um todo.

Palavras-chave: Escravidão; Império Romano; Alforria.

\begin{abstract}
This paper analyses the social and cultural influence of slavery in the Roman Empire. It investigates the frontiers between liberty and slavery in their public and private dimensions. It focuses on the concept of a trajectory of slave lives to set the freed slave in its proper dimension, something between slavery and liberty, a social condition that creates a zone of indetermination that affects society as a whole.

Keywords: Slavery; Roman Empire; Freedmen.
\end{abstract}

Um dos efeitos mais dramáticos da aceleração da integração mundial nos últimos vinte anos foi a implosão do conjunto de certezas sobre as quais repousavam as Ciências Sociais, incluindo-se nelas a História, em suas tentativas de explicar as sociedades humanas atuais ou passadas. Talvez nunca o passado, ou a memória sobre o passado, tenha se alterado tão rapidamente. A História Antiga, por exemplo, perdeu sua primazia, seu lugar de história primeira, de início de toda a história humana, para tornar-se apenas mais uma história, um dos vários caminhos que conduzem à contemporaneidade. $\mathrm{E}$, com efeito, numa época em que todos os pontos do planeta são relevantes para pensarmos o que somos e o que seremos, não faz mais sentido dar prioridade a uma história regional, localizada, que os intelectuais europeus dos séculos XIX e XX quiseram transformar na História por excelência da civilização, do homem em sua mais perfeita expressão e do mundo moderno como re- 
sultado da europeização da terra. Essa história, obviamente, não se basta, nem consegue dar conta da realidade complexa em que vivemos.

Isso não significa, contudo, que devamos abandoná-la. Não é nossa história antiga, mas ainda é uma história interessante e importante para nós. É parte de nossa tradição cultural e intelectual e uma porção significativa da história do mundo. E, sobretudo, dentre as várias histórias humanas, que hoje confluem para uma história global, é uma história à qual podemos propor perguntas que nos interessam, construir memórias que nos dizem respeito, seja construindo linhas diretas entre nós mesmos e esse passado, do qual derivamos, seja elaborando espelhos, que nos possibilitam olhar para o passado como algo diferente de nós, usando essas diferenças como um antropólogo usaria, para nos vermos sob um novo olhar.

O passado, como já disseram, é uma terra estrangeira. ${ }^{2}$ Temos a tendência a excluir o estrangeiro, assim como excluímos tudo que é diferente de nós. Mas essa posição é um preconceito e um empobrecimento de nós mesmos. Só sabemos o que somos, e por que somos assim, quando nos confrontamos com algo que é diferente de nós. Toda sociedade e todo ser humano vive e atua em um espaço de normalidade, em um conjunto de convenções compartilhadas, de expectativas sobre as posições e os comportamentos alheios, que torna a vida em sociedade possível, mesmo que conflituosa. ${ }^{3} \mathrm{O}$ estudo do passado nos ensina que a nossa própria normalidade é histórica, que é passageira, que outras normalidades foram possíveis, assim como o serão no futuro. Ensina-nos, no fundo, que nada é normal, que tudo é convenção e que a realidade é apenas o limite de nossas convenções.

$\mathrm{O}$ estudo da história antiga nos coloca frente a frente com nossas convenções. Quando falamos em sociedade romana, a que nos referimos? A uma sociedade como a nossa? Ou a algo diferente? Vejam bem: para estabelecer a diferença, temos que estabelecer o que somos. Esse é, para mim, o grande sentido da história. Não é a celebração de eventos ou de grandes homens, não é a glorificação do passado nem a reificação da memória. A História científica é interessante porque, para pensar o passado, temos que nos pensar. Para ver e estabelecer diferenças, ou semelhanças, ou a igualdade, temos que definir o que somos, ou o que fomos num passado não tão remoto.

Aqui me interessa um tema em particular. Pensemos, por um momento, em um mundo muito distante do nosso, separado de nós por dois mil anos de história e milhares de quilômetros de distância: o mundo da escravidão antiga. Minha pergunta geral será a seguinte: quais os efeitos que a presença maciça de escravos pode produzir numa sociedade e, mais especificamente, 
quais efeitos produziu na sociedade da Itália Romana. Talvez, é o que espero, seja uma maneira interessante de colocarmos questões que nos são pertinentes.

Começo com uma advertência. O Império Romano conheceu diferentes formas de trabalho compulsório, dentre elas uma que denominamos de 'escravidão' Ou seja, ao contrário do mundo moderno, a escravidão antiga sempre conviveu com outras formas de dominação de pessoas e de exploração de trabalho dependente. ${ }^{4}$ No mundo antigo havia todo um espectro de situações de dependência entre a escravidão e a liberdade. A escravidão representava apenas uma das pontas desse espectro. De qualquer modo, em alguns períodos e lugares, foi a forma dominante por vários séculos, em particular na Itália romana entre os séculos II a.C. e II d.C. É aqui que devemos procurar por eventuais efeitos da escravidão sobre a sociedade em geral. Antes disso, no entanto, uma outra advertência importante.

Não é fácil definir a escravidão antiga. A historiografia trata em geral a escravidão como se fosse um fenômeno quase universal, presente, em diferentes graus de intensidade, em quase todas as sociedades humanas pré-capitalistas. Nossa imagem do que seja ou tenha sempre sido a escravidão é calcada na experiência da escravidão colonial nas Américas, particularmente as do sul dos Estados Unidos, do Caribe e do Brasil que, por sua vez, buscaram grande parte de seus fundamentos jurídicos e de sua legitimação no direito romano. A noção mais comum continua sendo de caráter eminentemente legal: a do escravo propriedade, sempre um estrangeiro, adquirido para ser uma coisa pertencendo a outro indivíduo, que seria senhor, não somente de seu trabalho, mas de seu próprio corpo, do qual teria pleno e total direito de utilização e que poderia submeter a qualquer tipo de coação, castigo ou mesmo à execução simples e sumária. Para essa definição o escravo, por ser propriedade, seria uma coisa, uma condição, mas não um agente. Não devemos nos esquecer de que a própria noção de propriedade é culturalmente determinada, de que ela é específica para cada sociedade ou cultura e pode variar, com o tempo, no interior de uma mesma sociedade. ${ }^{5}$

A concentração da definição no fato da apropriação do próprio corpo, da pessoa do trabalhador e não apenas do seu trabalho ou dos produtos deste, fornece um parâmetro útil para compararmos essas relações de dependência, que eu chamaria de 'extremas', em diferentes sociedades e épocas. Mas devemos ter em mente que tais comparações são sempre feitas por analogia. Elas são um instrumento analítico, e não a prova a priori de uma plena identidade entre as várias 'escravidões' que encontramos na história humana.

É difícil comparar, para citar exemplos extremos, a escravidão ritual pra- 
ticada pelos tupis brasileiros, na qual o 'escravo', prisioneiro de guerra, ocupava o lugar e o nome de um membro da tribo morto em combate, com a escravidão voluntária e temporária que encontramos nos textos hebraicos, ou com o escravo africano moderno, transferido violentamente de outro continente por um amplo sistema comercial, o escravo etnicamente marcado: seja o negro estigmatizado, aquele do escravismo colonial anglo-saxão, na sua vertente paternalista do sul dos Estados Unidos, ou de sua versão mais radicalmente excludente, como no Caribe, ou daquela que nos é mais conhecida, a brasileira, que muitos autores recentes vêem como potencialmente mais integradora.

Assim como não há identidade, mas apenas analogia, entre as várias formas de 'escravidão' que podemos enumerar ou propor, tampouco podemos falar de uma fase escravista na história das sociedades humanas, como se fosse uma etapa necessária em direção às modernas relações capitalistas. Essa idéia, que teve muito trânsito na historiografia até recentemente, deriva de uma visão exclusivamente eurocêntrica da história humana, ao mesmo tempo em que generaliza, para a própria história européia, uma instituição cuja importância, numérica e social, só se tornou efetiva em certos momentos e lugares bastante específicos.

Nas sociedades que costumamos agrupar sob o nome enganoso de 'mundo antigo', seja nos grandes Impérios fluviais do Médio Oriente, seja nas cidades-Estado que depois se alastraram pelas margens do Mediterrâneo, nunca se constituiu um mercado abundante de mão-de-obra livre disponível para trabalhar para outrem. Daí advém que a carga de trabalho que excedia as capacidades de um grupo doméstico fosse sempre realizada mediante o uso de trabalhadores dependentes, ou seja, como dissemos, de trabalhadores submetidos a algum tipo de coação para trabalhar para outrem. ${ }^{6}$

A forma extrema dessas relações de dependência, que podemos, por analogia, denominar de 'escravidão', era aquela na qual o escravo era geralmente um estrangeiro, ou filho de mãe escrava, podendo ser comprado e vendido livremente no mercado e sobre o qual o proprietário exercia um imenso poder, embora não ilimitado. Mas essa forma foi uma exceção e nunca a regra nesse chamado 'mundo antigo'. Foi característico do mundo das cidadesEstado, mas não de todas elas, e sobretudo do Império Romano mas, como já disse, não em todas as suas regiões, nem com a mesma intensidade em toda sua duração. Nem mesmo podemos afirmar que seu estatuto tenha sido uniforme em todas as cidades-Estado nas quais adquiriu importância. Era, por exemplo, algo muito diferente o ser escravo na Atenas clássica ou na Roma 
republicana, não apenas em termos legais, mas no tocante à própria inserção social dos escravos.

Algumas condições parecem ter sido necessárias para o desenvolvimento desse tipo extremo de relação de dependência que poderíamos denominar de escravidão mercadoria. A principal é econômica: a difusão da escravidão mercadoria está diretamente ligada ao desenvolvimento do comércio e ao crescimento e concentração de riquezas em algumas cidades-Estado mediterrânicas, particularmente nos grandes portos comerciais, como Egina, Corinto e Atenas, que também eram centros de produção artesanal; ou nas capitais de grandes Impérios, como o ateniense do século $\mathrm{V}$ ou a Itália romana, que carreavam recursos, na forma de tributos, de vastas periferias dominadas e, por fim, associadas às duas últimas, nas áreas que produziam bens agrícolas destinados ao mercado marítimo, como o azeite e o vinho. Seu desenvolvimento foi uma função, ao mesmo tempo, do enriquecimento dessas cidades-Estado e da concentração de riquezas e meios de produção (como oficinas artesanais e, sobretudo, terras) nas mãos de alguns membros da comunidade cidadã. Foi essa nova capacidade e possibilidade de produzir mais e de vender o excedente da produção que esteve na origem do crescimento da escravidão mercadoria em cidades como Atenas ou Roma.

Em algumas cidades-Estado e regiões do Mediterrâneo, como a Itália central ou a Sićlia, a escravidão mercadoria adquiriu uma importância considerável. É nessas regiões, nos séculos iniciais do Império, que vou centrar minha atenção. Os escravos tornaram-se uma parcela significativa da população: algo perto de um terço da população total, como uma estimativa modesta. ${ }^{8}$ Tornaram-se, igualmente, a principal força de trabalho dentro dessas comunidades, praticamente monopolizando os serviços domésticos, não diretamente produtivos, e tendo uma importância crescente na produção artesanal e, sobretudo na Itália e na Sicília, na produção agrícola destinada ao mercado.

A despeito de sua importância social e econômica, a escravidão ocupa, na historiografia sobre o Império Romano, uma posição ambígua que deriva, a meu ver, do fato de os escravos serem parte importante da sociedade, ao mesmo tempo em que estavam excluídos da comunidade política. Há aqui uma disjunção que a historiografia assimila com dificuldade. Os escravos estavam presentes, reconhece-se, e muitas vezes maciçamente, no mundo da produção, do trabalho, mas parecem não ter exercido nenhuma influência na esfera política e, menos ainda, na cultural..$^{9}$ À parte algumas grandes revoltas episódicas, das quais a mais famosa é a de Espártaco, a presença maciça de escravos parece ter influído muito pouco sobre o restante da sociedade. Traba- 
lhavam para seus senhores, eram seus instrumentos, revoltavam-se raras vezes, e nada mais. Será apenas isso? Creio que não.

A meu ver, os escravos penetraram com grande força no tecido social da Itália romana, de uma maneira muito mais intensa e completamente distinta do que se costuma pensar com relação à escravidão colonial moderna. Essa inserção deve-se à grande plasticidade da escravidão no mundo romano, seja como forma de relação social, seja como forma de relação de poder e exploração. Para entendermos essa plasticidade em todas as suas conseqüências quero introduzir uma noção, desenvolvida por O. Patterson em seu livro Slavery and Social Death, ${ }^{10}$ que me parece particularmente relevante para entendermos a escravidão mercadoria antiga: a noção de trajetória. Mesmo que não aceitemos por completo as idéias de Patterson sobre a oposição entre liberdade e escravidão, algumas de suas noções são úteis para compararmos 'escravidões' distintas.

Para Patterson, a escravização pode ser entendida como um processo de morte simbólica, no qual o escravizado perde sua identidade original, sua pessoa, para tornar-se quem seu senhor determinar. Mas não se transforma, nesse processo, numa coisa, a despeito de como o direito tente definir sua persona social. Pelo contrário, é ressocializado dentro da sociedade em que nasceu ou que o escravizou, seguindo trajetórias determinadas, tanto pelos desejos e necessidades de seu dono, como por suas próprias capacidades e oportunidades individuais. Sociedades diferentes estruturam trajetórias distintas para seus escravos e, no mundo romano, essas trajetórias eram bastante amplas, ao menos potencialmente. Um escravo, ao nascer ou ser adquirido, entrava na casa de seu senhor, onde adquiria um nome e uma função. Podia ser destinado a trabalhar nas minas, talvez o pior dos destinos, ou podia ser mandado para uma propriedade rural, onde trabalharia muitas vezes acorrentado, distante e esquecido por seu senhor, num ambiente essencialmente masculino e organizado militarmente.

Já os escravos urbanos tinham trajetórias mais abertas. Podiam ser treinados em ofícios específicos e, muitas vezes, estabelecer-se independentemente, pagando uma taxa a seu dono. Podiam trabalhar na residência de seu senhor, ganhar sua confiança e passar, por exemplo, a administrar seus negócios, a gerir suas propriedades agrícolas, a comerciar em seu nome. Como ponto final da trajetória, podiam obter sua alforria, tornarem-se libertos e, até mesmo, cidadãos romanos, ainda que carregando a mancha da escravidão, da qual só seus filhos se libertariam plenamente.

Chamo a atenção para esse ponto: é importante, como veremos a seguir, 
considerar o forro não simplesmente como uma pessoa livre, mas como alguém que foi libertado, como o ponto final da trajetória escrava e não, como usualmente se faz, como a negação da escravidão. ${ }^{11} \mathrm{O}$ liberto situava-se numa zona de fronteira entre a escravidão e a liberdade, uma espécie de limbo, uma área da qual as classificações habituais não davam conta. O liberto era essencial para a normalidade romana, mas, em certo sentido, era também uma perturbação do normal.

Voltarei a esse tema. De qualquer modo, é importante ressaltar que a trajetória de cada escravo dependia de muitos fatores: de sua situação ao ser escravizado (se homem ou mulher, se prisioneiro de guerra, se nascido na propriedade), das necessidades do senhor, das circunstâncias do acaso e da habilidade do próprio escravo em desenvolver estratégias para sobreviver em sua condição e tentar superá-la.

Nas fontes romanas do último século da República e dos dois primeiros séculos do Império os escravos aparecem por toda parte nas fontes que se referem a Roma e à Itália. Algumas casas senhoriais chegaram a possuir centenas e mesmo milhares de escravos. Mas a importância de sua presença não era apenas numérica. Há outros elementos a considerar. Um deles é o da posição da escravaria no mundo da produção: os escravos parecem ter ocupado todas as posições chave na cadeia produtiva, da agricultura aos serviços domésticos. O trabalho e os problemas de gestão da escravaria dominam os tratados agrícolas romanos que possuímos, de Catão a Columella; também as inscrições da Itália romana, sobretudo da capital, revelam-nos escravos em todos os ramos artesanais; são igualmente ubíquos na literatura do período e, quase certamente, monopolizavam os serviços domésticos. A presença social e a influência econômica da escravidão não podem, assim, ser subestimadas.

Mas a existência de um grande número de escravos tinha também conseqüências políticas, pois afetava diretamente as relações de poder entre os cidadãos livres. A expansão da escravidão na Itália romana aprofundou o fosso que separava os cidadãos ricos dos pobres (e que eram, na visão dos próprios antigos, as principais forças em luta na cidade-Estado antiga). Possuir escravos tornou-se um meio de acumular riqueza, em homens e em força produtiva, homens que podiam ser usados para proteger, para afirmar a própria riqueza de seus senhores, e até mesmo para coagir outros cidadãos, mas que permitiam, também, fazer render a riqueza. Escravos podiam ser adquiridos para produzir mais riquezas, tornando assim interessante e viável a aquisição e exploração de mais meios de produção, como terras, oficinas e instrumentos de trabalho. Ao contrário do que se pensa geralmente, a presença expres- 
siva de escravos não foi um entrave ao desenvolvimento econômico no Império Romano, mas incentivou-o, permitindo não apenas entesourar a riqueza, mas investi-la. A própria presença dos escravos tornou os ricos mais ricos e, portanto, aumentou suas forças nos embates com os cidadãos mais pobres. A riqueza extraordinária de certos membros da aristocracia senatorial romana só foi possível, e só é compreensível, pela presença maciça de escravos.

Além disso, como vimos, na ponta final de sua trajetória o escravo podia se tornar cidadão, mas não se tornava, por conseqüência, livre por nascimento. ${ }^{12}$ Passava a fazer parte de uma ampla categoria, a dos libertos. Estes, a despeito de se tornarem homens livres e mesmo quando adquiriam o estatuto de cidadão, permaneciam ligados a seus antigos senhores por obrigações que iam da prestação de serviços banais, como acompanhar seu ex-senhor ao centro da cidade, até o pagamento de taxas. De modo geral, pressupunha-se que mantivessem um respeito obsequioso frente a seus antigos senhores, seus 'patronos. "Pai e patrono devem ser sempre respeitados e sagrados aos olhos de um liberto ou de um filho", afirmava o jurista Ulpiano no início do século III de nossa era (Digesto, 37, 15).

A libertação dos escravos, dessa maneira, introduzia no corpo dos homens livres e mesmo no conjunto dos cidadãos, relações de dependência e submissão que não eram totalmente voluntárias. A ligação que permanecia com seus ex-senhores, seus patronos, os tornava em certo sentido menos livres que os nascidos livres, os chamados ingênuos. A alforria, dessa forma, instituía graus distintos na esfera da liberdade privada. Criava graus na liberdade. Uns haviam nascido livres, outros, os libertos, traziam a mancha da escravidão em seus corpos. E deviam respeito e obrigações a seus patronos... mesmo sendo livres. Perturbavam, assim, a liberdade.

Veremos, na seqüência, como os romanos tentaram lidar com essa ambigüidade. Uma outra faceta da escravidão romana talvez nos seja mais difícil de apreender, mas é de suma importância. A escravidão era, para os romanos dessa época, um fato normal da vida, como o trabalho assalariado é para nós. Alguns podiam apontar um dedo repreensivo para um senhor muito cruel, que torturasse seus escravos sem motivos, ${ }^{13}$ mas a escravidão, a posse do corpo de outrem, bem como os castigos corporais, eram fatos da vida que ninguém discutia. ${ }^{14}$ Mais importante ainda: ser escravo era apenas uma circunstância da vida, uma posição específica dentro da sociedade e não uma anomalia. Escravos e livres não se separavam, a não ser por sua condição jurídica. Esta última não podia, obviamente, ser transgredida impunemente. Mas a condição jurídica era apenas uma das dimensões do espaço da vida co- 
tidiana. Nesta, livres e escravos conviviam lado a lado, exerciam ofícios semelhantes, compartilhavam desejos, aspirações, reivindicações, teciam redes de vizinhança e de amizade. Várias fontes sugerem que não havia uma separação tão nítida entre mundo escravo e mundo livre como se costuma supor. Na famosa carta 47 de Sêneca a Lucílio, o autor repete inúmeras vezes o mesmo mote: "são escravos, mas são homens". A mesma expressão aparece em um romance escrito, provavelmente, no reinado de Nero, o Satyricon de Petrônio, ao qual voltarei, no qual um dos protagonistas, o rico liberto Trimalcião, afirma que: "os escravos são homens e beberam do mesmo leite, mesmo que o mau fado os tenha oprimido" (Satyricon, 71). Para dar outro exemplo, nos collegia funeraticia, que eram uma espécie de confraria religiosa e profissional que garantia um enterro digno e o culto apropriado a seus membros após a morte, livres, libertos e escravos participavam em pé de quase igualdade. ${ }^{15}$ Que não fosse possível diferenciar de imediato, na massa dos habitantes de Roma, os homens livres da plebe e os escravos é algo sugerido por Sêneca, no livro III, 22 do Tratado sobre a Clemência, que citamos há pouco, escrito para o jovem Nero. Sêneca conta que, uma vez, o Senado decidiu que os escravos deveriam vestir-se de modo especial, mas abandonou a idéia, pois, se os escravos tivessem noção de sua quantidade, ameaçariam o mundo de seus senhores.

Essa idéia de coexistência, de compartilhamento do espaço da vida, por homens de condições distintas, é reforçada por vários outros testemunhos. Tácito, escrevendo sobre a plebe romana à época de Nero, faz um dos conselheiros do imperador afirmar que boa parte da plebe de Roma, da classe eqüestre e mesmo do Senado tinham origem servil — quase todos tinham um ascendente que fora escravo (Anais, XIII, 27). Diz Tácito, em sua linguagem peculiar:

pois esse corpo (o dos libertos) difundiu-se largamente. Dele as tribos, as decúrias, os auxiliares dos funcionários e sacerdotes, as coortes, mesmo as alistadas na capital; e a maioria dos cavaleiros e muitos senadores não têm outra origem. Se separassem os libertos, seria evidente a penúria dos nascidos livres, os ingênuos. Não foi em vão que os antepassados separaram a dignidade das ordens, mas colocaram a liberdade em comum.

O episódio histórico mais significativo, ao menos durante o Principado, talvez seja o do assassinato de Pedânio Segundo, prefeito de Roma sob Nero. ${ }^{16}$ A seqüência de eventos nos é relatada por Tácito em seus Anais, no livro 
XIV, 43: o prefeito fora assassinado por um de seus escravos mais próximos, ou porque a liberdade prometida lhe fora negada ou por ciúmes de outro escravo mais jovem. Uma antiga lei ordenava que todos os escravos sob o mesmo teto fossem sacrificados. E eram quatrocentos, incluindo mulheres e crianças. O jurista C. Cássio defendeu sua execução em massa com os seguintes argumentos: "quem será protegido por sua dignidade, se ela não ajudou ao prefeito da cidade de Roma? Quem será protegido pelo número de escravos, se os quatrocentos de Pedânio Segundo não o auxiliaram?". Cássio defendia a execução como instrumento de coação, como exercício público do poder para garantir o poder privado (44): "e se temos verdadeiras nações em nossa escravaria, com rituais diferentes, distintas coisas sagradas, ou mesmo nenhuma, essa lama só dominareis pelo medo". O medo devia vir do Estado. O domínio privado do senhor sobre seus escravos era questão de ordem pública.

Os escravos pareciam existir apenas na e para a esfera privada, mas o controle de sua potencial ameaça era público. A camada dos grandes senhores de escravos (obviamente com o apoio de todo senhor de escravos que não se sentisse seguro, quisesse firmar sua autoridade ou, simplesmente, mostrar-se superior à escravaria) pedia ao Imperador o apoio público para uma medida normalmente restrita ao âmbito particular: a execução de escravos. A posição dos herdeiros de Pedânio, proprietários putativos dos escravos, é irrelevante para Tácito. Ele, simplesmente, não os menciona. O que os mais ricos pediam ao Imperador era que este considerasse o crime de um escravo como crime público e que assim fosse tratado, fazendo de todos os escravos de uma mesma casa co-responsáveis pelo assassinato. Os conflitos em torno da decisão foram conflitos públicos. É interessante observar quem — se é que alguém - aliou-se publicamente com os escravos.

Tácito nos diz que a plebe de Roma revoltou-se e tentou impedir a execução: "uma multidão aglomerada ameaçava com pedras e paus. Mas César censurou o povo em um edito e mandou cercar com soldados todo o caminho que conduziria os condenados ao suplício" (Anais, XIV, 45). Por que se aglomerou a plebe? Talvez porque o castigo fosse injusto. Mas isso só seria percebido e sentido por pessoas que temessem sofrer o mesmo destino ou que fossem próximas, de alguma maneira, aos condenados. P. A. Brunt, em seu artigo "The Roman Mob", ${ }^{17}$ sugeriu que livres pobres e escravos, que compunham a plebe urbana de Roma, vivessem lado a lado uma vida comum. Nas camadas mais pobres da metrópole as diferenças de condição social ou jurídica contavam pouco. Viviam-se vidas em comum, mesmo que desiguais.

Vidas em comum! Como ampliar esse conceito? Talvez seja menos difí- 
cil do que parece. Muitos homens livres ligavam-se às grandes casas da cidade de Roma, como os clientes à procura de um bom patrono, de quem esperavam ajuda no sustento diário e, se possível, alguma promoção social. Faziam filas de madrugada à soleira de seu senhor, dispostos em ordem segundo sua condição e seu prestígio social, para saudá-lo quando acordasse, para acompanhá-lo ao fórum, em troca de uma pequena cesta de alimento, de um convite para jantar, de uma indicação política. Eram livres, mas não tinham vergonha de depender.

A própria plebe de Roma, ao que parece, assumira como seu patrono o imperador, de quem esperava garantia de sobrevivência e um pouco de distração. Não é outro o sentido dos célebres versos de Juvenal, em sua sátira X: "pois quem antes conferia o império, os feixes, as legiões, tudo, agora se contém e duas coisas apenas ansiosamente deseja, o pão e o circo". Note-se, entretanto, que a relação de patronato, aqui, não se restringia à esfera privada, era claramente pública. Colocava plebe e imperador num processo de interação, de negociação, de aprovação ou censura que extrapolava as relações privadas entre patrono e cliente ou entre patrono e liberto. Se associarmos essa idéia ao episódio do assassinato do prefeito, essa plebe que reivindicava parece combinar livres, libertos e escravos. Uma plebe na qual e para a qual as diferenças de dignidade e de condição jurídica eram pouco relevantes. É uma possibilidade real, ainda que não possamos prová-la.

Entre livres e escravos havia assim talvez mais ligações e mediações do que estamos acostumados a pensar. Para compreendê-las temos que suspender, por um momento que seja, o modo como diferenciamos público de privado. As relações eventuais entre membros da plebe, ou do populus, ${ }^{18}$ como as entre livres e escravos, eram privadas e pessoais. É algo muito distinto das relações entre patrono e ex-senhor, ou senhor e escravo, que eram publicamente privadas, pois dependiam de um poder privado que se definia e garantia publicamente. Que eram, por sua vez, distintas daquelas efetivamente públicas se, como acredito, as houvesse: aquelas efetuadas no espaço comum e mediano do Estado, mediado pelo imperador. A dimensão pública, de qualquer modo, ressalta uma diferença crucial entre livres e escravos: o fato de que a inserção dos escravos na sociedade era mediada necessariamente pela casa na qual serviam. Ao menos teoricamente, o escravo não tinha existência pública, não era uma pessoa, mas uma coisa, uma propriedade de seu senhor, de cujo corpo este podia dispor a seu bel-prazer.

As nuances entre público e privado são essenciais para entendermos a escravidão romana, pois a trajetória escrava turvava as fronteiras entre dife- 
rentes articulações da vida social. A decisão de Nero no caso do prefeito Pedânio Segundo parece-me emblemática: o imperador e o Império não apenas reconheciam como legítimo, mas se propunham a defender com a força militar o poder privado dos senhores sobre seus escravos. Entre escravos e livres havia uma linha, portanto, que todos os imperadores respeitariam, que não podia ser ultrapassada. O poder político, público, se propunha como garantidor dos poderes privados. Mas e os ex-escravos? A quem pertenciam? A que esferas podiam apelar, caso pudessem?

Volto aqui à questão dos escravos alforriados, os libertos, porque me parece crucial para entendermos a influência da escravidão na sociedade romana. Não é possível definir, estatisticamente, qual a porcentagem de escravos alforriados, em determinado período ou região, frente ao total da escravaria. É fato que a grande maioria das inscrições funerárias que possuímos no Império são relativas a escravos libertos, mas isso não significa que fossem a maioria da população. Talvez fossem apenas aqueles que tinham mais condições, ou que julgavam mais importante e significativo expor sua trajetória em público, como marco de sua vida. Mesmo que sua entidade numérica fosse reduzida, no entanto, formavam uma categoria social importante: muitos libertos, dependendo da casa à qual pertenciam, tornavam-se homens respeitados, muitas vezes ricos e algumas vezes poderosos. Os libertos do imperador, em particular, sobretudo no século I d.C., acumulavam poder, prestígio e riquezas, a ponto de competirem com a nobreza senatorial. Dessa forma, produziam um curioso fenômeno social, na medida em que seu status prestigioso não correspondia à sua condição social previsível.

Os libertos existiam em uma espécie de zona de turbulência entre as dimensões públicas e privadas. Eram um matiz a mais num mundo de matizes. Embora nunca se separassem definitivamente do universo privado do qual haviam emergido, adquiriam uma existência pública que demandava uma regulamentação por parte do Estado. Já desde o final da República houve um esforço consciente e concertado para enquadrar a situação dos libertos. Augusto, no processo de ordenação que deu origem ao Principado, limitou a capacidade de os privados libertarem seus escravos por testamento e estabeleceu graus distintos de liberdade, que conferiam graus distintos de cidadania. Essa tensão entre esferas públicas e privadas tornou-se especialmente aguda à época de Nero. Segundo Tácito (XIII, 26-27), em 56 discutiu-se no Senado romano sobre a situação dos libertos. Pedia-se, diz ele, que os patronos tivessem o direito de revogar a liberdade de seus libertos em caso de ingratidão. Muitos não cumpriam com suas obrigações e ofendiam abertamente seus ex- 
senhores, seus patronos. Decidiu o Imperador Nero, após longa deliberação em seu conselho, que cada patrono deveria avaliar em privado a situação de seus libertos. A liberdade, como vimos, havia sido colocada pelos antepassados in commune, no meio de todos, no espaço público, e aí devia ser mantida. O príncipe, desta forma, garantia a liberdade pública dos ex-escravos. Liberdade comum... liberdade de quem? Que significava liberdade sob o Império Romano?

Resumamos os dados obtidos até o momento. Que a presença de escravos e de libertos fosse importante em termos econômicos está fora de questão. Ninguém na historiografia contemporânea contesta esse ponto. Que penetrassem em todos os poros da sociedade romana, afetando suas relações de poder, confundindo as esferas do público e do privado e contaminando as relações sociais como um todo, parece ser uma conclusão plausível a partir do que expusemos aqui. Gostaria, para concluir, de tratar de uma outra dimensão - a da cultura - que não se separa das anteriores, a não ser arbitrariamente - mas que é mais difícil de definir e de localizar. A pergunta é: podemos atribuir quaisquer mudanças culturais à ubiqüidade do escravo no mundo romano? Deixo claro que é uma pergunta que podemos e devemos fazer a nós mesmos, mas aqui me centrarei no caso romano.

De modo geral, não é possível falar de uma cultura escrava no Império romano. Ou, ao menos, é muito mais complexo do que, talvez, no caso da escravidão brasileira. Os escravos romanos não tinham nenhuma identidade étnica ou racial. Pelo contrário, as fontes ressaltam, precisamente, a estratégia de diversificar as origens da escravaria para impedir o surgimento dessas identidades. A ausência de um estigma racial, de uma clara identificação do escravo pela cor da pele, vestimenta ou origem étnica, contribuía para tornálos potencialmente invisíveis na sociedade. E essa invisibilidade, como vimos em Sêneca, era um instrumento de controle e de dominação. Porém, o próprio caráter aberto da cultura romana, capaz de absorver as influências mais diversas, tanto eruditas, tal como as provenientes do mundo grego, quanto religiosas e populares, procedentes do Oriente ou das populações conquistadas a ocidente, torna muito difícil definir um espectro cultural que fosse específico dos escravos. Seria impossível, por exemplo, identificar uma divindade própria apenas aos escravos ou perceber na filosofia de Epíteto o fato de seu autor ser um ex-escravo, a não ser pelo fato de afirmar isso explicitamente. E mesmo no universo anti-romano, ou não romano, do cristianismo primitivo, o credo religioso não distinguia escravos de não escravos, a não ser pelas obrigações distintas de tratamento justo e de obediência. 
Mando e obediência. Pólos opostos e complementares, entre os quais não apenas os cristãos, mas os romanos em geral, classificavam os membros da sociedade. Entre esses pólos, a escravidão ocupava um lugar essencial, mesmo que ambíguo. O escravo situava-se no cúmulo da obediência, cuja transgressão pagava com o próprio corpo, senão com a vida. Muitos obedeciam, mas só os escravos deviam obedecer ou pagar na carne pela desobediência (aos livres e pobres sempre restava a alternativa da fome). Esse é um dos extremos da trajetória. No outro pólo, temos a libertação, a possibilidade de alforria do escravo. Se aceitarmos a idéia de que os escravos cumpriam uma trajetória e de que esta se finalizava com os libertos e os incluía, devemos aceitar o fato de que estes concretizavam e simbolizavam uma possibilidade real de ascensão social, num mundo onde essa possibilidade era escassa. Dito em outros termos: por menor que fosse sua entidade numérica ou sua proporção frente ao conjunto da escravaria, a existência de escravos forros exercia um efeito crucial na sociedade. Mesmo que fosse uma tênue luz no fim de um longo túnel, ainda que fosse acessível a poucos, era ainda uma luz, um foco que conferia sentido ao viver social e que concentrava as aspirações de boa parte dos membros da sociedade romana. Não me parece à toa que Nero, como vimos, após ouvir as diferentes posições com relação à liberdade dos exescravos, se decidisse por reforçá-la, por reafirmá-la, realçando, em seu conselho privado e de modo contundente, o alcance público de atitudes que pudessem ser eventualmente tomadas no âmbito privado pelos membros mais ricos da ordem pública: os senhores de escravos. Nero pôs um limite público a seu poder privado. Foi um dos primeiros a fazê-lo.

Voltemos ao mundo representacional da cultura. Se aceitarmos a idéia de que escravos e forros pertenciam a um mesmo mundo que, por sua vez, não se distinguia da cultura romana em geral, mas participava dela, há uma fonte que nos permite, melhor que qualquer outra, penetrar nesse universo ao mesmo tempo particular e geral: o Satyricon de Petrônio. Esse é o mais antigo romance em língua latina preservado pela tradição. Mutilado ao longo dos séculos, chegou até nós de modo tão fragmentado que é quase impossível fazermos uma idéia da trama original que articulava seus diferentes episódios. É possível, no entanto, estabelecer a unidade do enredo através da figura do narrador, um homem livre, culto, mas pobre e desenraizado, de nome Encólpio. Em torno deles se juntam os demais protagonistas que atravessam vários, embora não todos, os episódios do romance: o professor Agamenon, o valente Ascilto, o letrado Menelau e Gitão, aparentemente escravo e objeto sexual dos demais protagonistas. O episódio mais bem conservado é o de um 
banquete oferecido por um liberto rico, chamado Trimalcião, ao qual comparecem Encólpio, Ascilto, Agamenon e Gitão.

O episódio do banquete, a bem da verdade, parece circunstancial à trama. É possível, e talvez seja provável, encontrar nele uma crítica à realidade contemporânea e, quiçá, à própria corte de Nero, ou de Cláudio. Trata-se, como se sabe, de uma sátira, e os personagens aparecem deformados pela ironia, pelo exagero, pelo olhar profundamente crítico do autor. ${ }^{19}$

Petrônio, de qualquer modo, descreve uma situação, um espaço de convivência, que é tipicamente romano: o banquete. E põe em ação no banquete personagens que, em si, nada têm de irreais (do contrário sua sátira perderia o sentido). É um banquete de libertos, oferecido pelo mais rico deles, Trimalcião, a um grupo de amigos, conhecidos e conhecidos de conhecidos (os 'penetras'). Os participantes do banquete possuem diferentes condições sociais: a maioria é composta por libertos, muitos deles co-libertos de Trimalcião, uns são ricos, outros pobres; Agamenon é o único livre convidado, mas vai ao banquete com três amigos, Encólpio (o narrador) e Ascilto, ambos livres, e Giton, que aparece na cena como escravo do último. Por fim, a casa de Trimalcião e o próprio banquete são povoados por escravos, que servem aos convivas segundo suas diferentes especialidades.

Há uma peculiaridade intrigante no banquete: nenhum liberto tem patrono, nem parece dever qualquer obrigação a alguém, nem tem filhos que possam nascer livres. Todos estão presos à sua condição de libertos. O próprio Trimalcião relata como sua riqueza adveio do patrimônio que lhe fora deixado por seu ex-senhor, que ele próprio fez render pelo comércio e, depois, pela usura. Mas o ex-senhor não aparece, morreu. São ex-escravos sem seus ex-senhores. Um grupo risível para um membro da aristocracia imperial como Petrônio, mas cujo modo de vida era, muito provavelmente, o ideal quase inalcançável da escravaria. Nesse mundo sem senhores, em que os forros eram donos de si mesmos, que visão expressavam do mundo, ao menos pelos olhos críticos de Petrônio?

Em primeiro lugar, e isso é bastante claro no banquete, os escravos eram escravos, nasciam escravos, eram adquiridos como escravos, podiam ser espancados, torturados e mortos pela vontade de seu dono. Trimalcião exercia sem peias seu poder de senhor, mesmo quando o teatralizava (ou seja, quando fingia que ia castigar, mas acabava perdoando o escravo).

Em segundo lugar, a liberdade se conquistava, não era apenas uma graça concedida, pois dependia de o escravo servir plenamente, sem titubear. O próprio Trimalcião fora o brinquedo sexual de seu ex-senhor e de sua ex-senhora 
e não se envergonhava disso. Ele mesmo, assim como o outro liberto extrarico do banquete, Habinnas, tinham seus próprios brinquedos sexuais, dos quais não abriam mão. Mais que isso, a liberdade era um prêmio tardio, freqüentemente post mortem, mas essencial, pois atuava como mecanismo de controle da escravaria. A relação pode nos parecer perversa, mas fazia sentido para o escravo romano: os escravos eram hierarquizados, os administradores compartilhavam parte do mando de seu senhor, tornar-se-iam libertos e herdeiros, e seus filhos, se os tivessem, nasceriam livres, sem manchas.

Sua liberdade é a isca para o controle dos demais: cabe a um escravo servir bem e subir na ordem da escravaria. Essa pequena janela era capaz de impedir eventuais identidades horizontais entre os escravos. Cada escravo lutava, não contra a escravidão, mas contra sua própria situação como escravo. Havia várias estratégias possíveis (para alguns) e várias maneiras de um liberto posicionar-se frente ao mundo dos livres.

No banquete de Trimalcião, por exemplo, alguns libertos se relacionam com a esfera pública, seja participando, seja demandando. Alguns libertos fazem demandas ao espaço público: pedem pão barato e criticam as autoridades corruptas, ou pedem bons espetáculos de gladiadores. As mesmas que Juvenal atribui à plebe de Roma, como vimos, pão e circo, a mesma reclamação quanto à falta de energia do povo: "antes éramos como leões, diz o liberto Echion; agora somos raposas". Libertos, escravos e pobres parecem assim compartilhar certa condição, certos valores.

Os mais ricos, como Trimalcião e Habinnas, exercem cargos públicos de prestígio, atuando no culto ao imperador estabelecido por Augusto, o sevirato, e relacionado-se com pessoas bem nascidas e prestigiosas. Os mais ricos não demandam senão reconhecimento institucional. O espaço público parece ser algo distante, institucional. Não se propõem ao evergetismo dos ricos livres. Sua riqueza não é meio de publicização, é fonte de poder privado e símbolo de sua ascensão, algo que deve ser ostensivamente exposto. É o índice de seu sucesso pessoal e, no banquete, o alvo do desejo dos libertos. No Satyricon, a riqueza de um liberto compõe-se de bens (terras, escravos, metais); de amigos bem localizados (ingênuos); de seus co-libertos; de certa cultura (afetada ou manifesta na presença de Agamenon); da capacidade de oferecer um lauto banquete e de ter um belo túmulo.

A cultura, mesmo que apareça deformada pelo tom satírico da obra, é altamente valorizada. É certo que as referências à alta cultura literária, a Homero ou à mitologia grega, aparecem distorcidas e são risíveis. O próprio Trimalcião despreza os filósofos, ou seja, despreza a cultura fechada em si mes- 
ma. Mas os libertos apreciam, no romance, a boa educação formal, as primeiras letras, os números, o aprendizado de um ofício. É algo que se leva para a vida toda, um bem indestrutível. Vale a pena olhar mais de perto para os valores expressos pelos libertos no banquete, por mais distorcida que seja a visão que deles nos oferece Petrônio.

No banquete de Trimalcião, os libertos mostram algumas características interessantes. Os libertos não têm vergonha de sua origem. O próprio Trimalcião mandou pintar sua trajetória nas paredes da casa e muitos outros libertos descrevem suas trajetórias com orgulho. Para eles, a escravidão não manchava. O sucesso e a riqueza limpavam qualquer mancha. Daí provêm as outras características. Os libertos eram muito individualistas. Nenhum liberto pensava-se como parte de uma categoria ou classe. Todas as trajetórias do Satyricon são individuais. O sucesso ou fracasso de cada um dependeu de terem adotado certas estratégias na necessária relação de submissão ao senhor, quando eram escravos, e de sua agressividade aquisitiva frente ao mundo, quando foram libertados; para eles, a própria noção de trajetória parece ser uma categoria fundamental. A trajetória ideal seria guiada pela sabedoria em bem aplicar os recursos disponíveis, seja arriscando-os numa parada decisiva, como fizera Trimalcião, seja dedicando-os de modo mais controlado à aprendizagem de um ofício, o que garantia uma vida digna. Para os libertos do Satyricon, o mundo dos livres era diferente, era outro mundo. Mas não havia ruptura... era algo à mão, que podia ser tocado e experimentado, como no sevirato, e que funcionava como modelo do bom livre, do homem bom.

Nada disso impediu que, a certa altura do banquete, Trimalcião convidasse os escravos a se sentarem nos leitos e partilharem a comida. Encólpio, o narrador, sentiu-se horrorizado e reclamou do mau odor dos novos convivas. Diz ele: "Para que me alongar sobre isso? Quase fomos expulsos dos leitos quando toda a escravaria ocupou a sala de jantar. E notei o cozinheiro, que fizera de um porco um ganso, fedendo a molhos e temperos sobre mim”.

Mas ele, livre e pobre, era apenas um entre os convidados, podia reclamar em voz baixa, para o leitor, mas não podia rir. Quando seu amigo Ascilto resolveu rir das atitudes dos libertos, recebeu uma resposta direta e violenta, que resume o espírito do banquete:

Por que ris, cabeça de carneiro? Por acaso não te aprazem as delícias de meu senhor? Por certo és mais sortudo e costumas banquetear-te melhor. Graças ao espírito que protege esse lugar, não me sentei ao lado desse aí, senão teria calado esse latido. Fruta boa essa, que ri dos outros. Um fugitivo, andarilho noturno, 
que não vale a merda que caga. Em suma, se o cercasse, não saberia para onde fugir. Por Hércules, não fervo rápido, mas em carnes moles os vermes nascem. Ri. Mas ri de quê? Seu pai o comprou a peso de ouro? És cavaleiro, mas sou filho de um rei. E porque fui escravo? Pois me vendi como escravo, para ser cidadão romano e não um provincial que paga tributo. E espero viver de tal modo, que não seja motivo de riso para ninguém. Sou homem entre homens, ando de cabeça erguida, nada devo a ninguém. (Satyricon, 57)

Reforço a idéia expressa há pouco: nenhum liberto no banquete tem vergonha de sua origem. Pelo contrário, sua ascensão, desde a base, que não se escondia, era motivo de orgulho. Se entre livres e escravos havia mais vínculos, mais convivialidade do que geralmente se supõe, a presença dos libertos representava uma possibilidade concreta de ascensão social e criava um tipo social e cultural que certamente afetava a sociedade como um todo, mesmo que os autores aristocráticos não quisessem vê-la. Num mundo dividido em ordens e dignidades, o ex-escravo ocupava uma posição chave por sua própria indeterminação, por sua ambigüidade. Por ter ascendido, por ter rompido uma barreira crucial, representava simbolicamente, para o corpo social, uma possibilidade concreta de ascensão, de mudança de posição, que acabava por amainar os conflitos potenciais de uma sociedade de posições muito rígidas.

Mas era ao mesmo tempo uma ameaça, contra a qual os grupos dominantes tentavam se defender, seja opondo-se aos libertos imperiais, cujo poder extrapolava violentamente sua própria condição jurídica, seja contra seus próprios ex-escravos, sobre os quais desejariam voltar a exercer um controle mais rígido, menos público, mais particular, ou antes um poder particular mais forte, garantido pelo poder público. Foi a isso que Nero se opôs, apesar das resistências. Quase cem anos depois, o imperador Antonino Pio tiraria aos senhores o poder privado de matar seus escravos... mas o mundo havia mudado e ninguém reagiu.

Para concluir: ao menos no mundo romano, mas desconfio que talvez em nosso mundo também, houve mais nuances entre a escravidão, ou a dependência, e a liberdade do que sonhavam nossos cientistas políticos. A libertação dos escravos criava, naquele mundo, uma zona de transição entre a escravidão e a liberdade, entre a dependência e a autonomia, que nossos olhos anti ou neoliberais, treinados pelo Iluminismo, não estão, talvez, acostumados a encarar. 


\section{NOTAS}

${ }^{1}$ Este artigo deve muito mais às discussões com os colegas Fábio Faversani e Fábio Duarte Joly do que seria possível reconhecer no texto ou nas notas de rodapé. Agradeço, igualmente, aos pareceristas da $\mathrm{RBH}$ pelos comentários, que permitiram eliminar vários problemas do texto original.

${ }^{2}$ LOWENTHAL, D. The past is a foreign country. Cambridge: Cambridge University Press, 1985.

${ }^{3}$ A noção de normalidade origina-se dos estudos sobre a História e a Sociologia do cotidiano. Veja-se GUARINELLO, N. L. História científica, história contemporânea e história cotidiana. Revista Brasileira de História, v.24, n.48, 2004, p.13-38. Sobre o tema, sob pontos de vista diferentes, vejam-se LEFEBVRE, H. Critique de la vie quotidienne. I. Introduction. Paris: L. Arché, 1958; CERTEAU, M. L'invention du cotidien.1. arts de faire. Paris: Gallimard, 1980; MAFFESOLI, M. A conquista do presente. Rio de Janeiro: Rocco, 1984; HELLER, A. Sociología de la vida cotidiana. Barcelona: Edicions 62, 1977 (1970); JAVEAU, Cl. La société au jour le jour. Écrits sur la vie cotidienne. Bruxelles: De Boeck-Wesmael, 1991, em particular p.82 ss.

${ }^{4}$ A noção de dependência substituiu, primeiramente, a idéia de uma escravidão generalizada no mundo antigo como era defendida pelo marxismo soviético. Para uma das primeiras elaborações da idéia, veja-se ANEQUIN, J. Claval-Lévêque, FAVORY, F. (Ed.) Formas de exploração do trabalho e relações sociais na Antigüidade Clássica. Lisboa: Estampa, 1978. Fundamental é ainda FINLEY, M. Entre a escravidão e a liberdade, economia e sociedade na Grécia Antiga. São Paulo: Martins Fontes, 1989, p.123-42.

${ }^{5}$ JOLY, F. D. A escravidão na Roma antiga: política, economia e cultura. São Paulo: Alameda, 2005.

${ }^{6}$ FINLEY, M. Ancient Slavery and Modern ideology. London: Chatto \& Windus, 1980, cap. II, passim.

${ }^{7}$ Ibidem.

${ }^{8}$ SCHEIDL, W. The Slave population of Roman Italy: Speculation and Constraints. Topoi, v.9, 1999, p.129-44; MADDEN, J. Slavery in the Roman Empire: Numbers an origins. Classics Ireland, v.3, 1996, p.1-6. Estimativa mais modesta em BRUNT, P. Italian Manpower 225 B.C. - A.D. 14. Oxford: OUP, 1971.

${ }^{9}$ JOLY, F. D. Libertate Opus Est. São Paulo: FFLCH, 2006 (Tese de doutoramento), cap I, para uma revisão e crítica da historiografia contemporânea, assim como DUMONT, J. Ch. Servus. Rome et l'Esclavage sous la République. Roma: EFR, 1987.

${ }^{10}$ PATTERSON, O. Slavery and Social Death. Cambridge (MA): HUP, 1982.

${ }^{11}$ WIEDEMANN, T. E. J. Slavery. Greece and Rome. Oxford: OUP, 1987.

${ }^{12}$ A lei Aelia Sentia, de 4 d.C., limitou a concessão de cidadania aos escravos, criando duas 
sub-categorias, os Junii Latini e os dediticii. É impossível, no estado atual dos conhecimentos, saber a proporção exata entre os escravos que se tornavam cidadãos e aqueles que permaneciam fora da cidadania romana. A principal fonte são as Institutae de GAIO, I, 1, 855.

${ }^{13}$ SÊNECA, De Clementia, III, 16.

${ }^{14}$ Por exemplo, SÊNECA, De Ira, III, 32.

${ }^{15}$ Por exemplo, Corpus Inscriptionum Latinarum (CIL), XIV, 2112.

${ }^{16}$ JOLY, F. D. Libertate Opus Est. São Paulo: FFLCH, 2006 (Tese de doutoramento).

${ }^{17}$ BRUNT, P. The Roman Mob. Past \& Present, v.35, 1966, p.3-27.

${ }^{18}$ Sobre a diferença, em alguns casos crucial, entre populus e plebs em Roma ver as considerações de VEYNE, P. Existait-il une classe moyenne em ces temps lointains. In: L'Émpire Gréco-Romain. Paris: Seuil, 2005, p.54-160.

${ }^{19}$ A bibliografia sobre o Satyricon é imensa. Um clássico sobre a obra é o texto de VEYNE, P. Vie de Trimalcion, em: La société romaine. Paris: Seuil, 1991, p.13-56. No Brasil, a obra de Petrônio produziu um dos mais interessantes debates nacionais sobre o mundo antigo (além de primorosas traduções). Veja-se FAVERSANI, F. A pobreza no Satyricon de Petrônio. Ouro Preto: UFOP, 1999. 